\title{
Effect of Levels of Nitrogen and Biofertilizers on Growth and Yield of Sunflower (Helianthus annuus L.)
}

\author{
Lakshman Jonnagorla*, Vikram Singh, Dhananjay Tiwari, \\ Shaik Mahaboob Ali and Balla Hari Krishna
}

Department of Agronomy, Sam Higginbottom University of Agriculture, Technology and Sciences, Prayagraj, Uttar Pradesh, India

*Corresponding author

\section{A B S T R A C T}

\section{Keywords}

Sunflower,

Nitrogen,

Biofertilizers,

Growth, Yield,

Economics

\section{Article Info}

Accepted:

12 December 2020

Available Online:

10 January 2021
A field Experiment was conducted during kharif 2019 at Central Crop Research Farm, Department of Agronomy, SHUATS, Prayagraj (U.P.). The soil of experimental plot was sandy loam in texture, nearly neutral in soil reaction $(\mathrm{pH} \mathrm{7.2),} \mathrm{low} \mathrm{in} \mathrm{organic} \mathrm{carbon} \mathrm{(0.58}$ $\%)$, available $\mathrm{N}(238 \mathrm{~kg} / \mathrm{ha})$, available $\mathrm{P}(32.10 \mathrm{~kg} / \mathrm{ha})$ and available $\mathrm{K}(189 \mathrm{~kg} / \mathrm{ha})$. The treatment consists of 3 levels of Nitrogen $(60 \mathrm{~kg} / \mathrm{ha}),(70 \mathrm{~kg} / \mathrm{ha})$ and $(80 \mathrm{~kg} / \mathrm{ha})$ and 3 application methods of Biofertilizers as seed treatment (Azospirillum), (Azotobacter) and (Azospirillum + Azotobacter), whose effect was observed on sunflower. There were 10 treatments each replicated thrice. The experiment was laid out in Randomized Block Design. The results showed that growth parameters viz. Plant height $(106.26 \mathrm{~cm})$ at 60 DAS, plant dry weight $(26.67 \mathrm{~g})$ at 60 DAS and Head diameter $(9.19 \mathrm{~cm})$ at 60DAS in $(80$ $\mathrm{kg} /$ ha Nitrogen + Azospirillum + Azotobacter $)$. The Yield parameters viz. Number of seeds per capitulum (373.67), Number of unfilled seeds per capitulum (13.33), test weight (41.10 g), seed yield (1351.15 kg/ha), stover yield (2954.29 kg/ha), oil content (43.52\%) Gross returns (76339₹/ha), Netreturns (49150₹/ha) and BC ratio (2.81) were recorded maximum with application of ( $80 \mathrm{~kg} / \mathrm{ha}$ Nitrogen + Azospirillum + Azotobacter $)$.

\section{Introduction}

Sunflower (Helianthus annuus L.) is one of the fastest growing and important vegetable oilseed crops in the world, native to southern parts of USA and Mexico and ranks fourth next to groundnut, soybean and rapeseed. In Greek "Helios" means sun and "anthos" means flower, popularly known as "Surajmukhi" or "Sooryakanthi" belonging to the family Asteraceae. The name is just for a plant that turns its flower to face directly into the sun as it passes and also looks like the sun in its yellow rays. Oilseed crops occupy an important position next to food grains in Indian economy. The oil not only forms an essential part in human diet but also serves as an important raw material for manufacture of various products like flavor enhancers, lubricants etc. Sunflower crop was introduced 
to India during 1969 as a supplement to traditional oilseed crops to bridge the gap of recurring edible oil shortage in the country. The commercial cultivation of sunflower started in India during 1972 - 1973 with an introduction of Russian varieties from USSR and Canada. Now, the crop is well adopted because of its desirable attributes such as short duration, photoperiod insensitivity, adoptability to wide range of soil and climatic conditions, drought tolerance, higher seed multiplication ratio (1:50) and high quality of edible oil (45 - 50\%), which contains polyunsaturated fatty acid (PUFA).

Sunflower (Helianthus annuus L.) is a temperate zone crop but it can perform well under varying climatic and soil conditions. In world it is cultivated on area of 18.12 million hectares with an annual production and productivity of 22.03 million tonnes and 1216 $\mathrm{kg}$ per hectare, respectively (Annonimus 2014-2015). Sunflower (Helianthus annuus L.) is one of the most important oilseed crops in India, grown in an area of $0.55 \mathrm{M}$ ha. with a production of 0.42 M.T. and productivity of $753 \mathrm{~kg}$ ha-1, respectively (Annonimus 20142015). The cultivation of sunflower is largely confined to southern parts of the country comprising the states of Karnataka, Maharashtra, Tamilnadu and Andra Pradesh. These four states contribute about $9 \%$ of total acreage and $78 \%$ of total production. Maharashtra ranks second in area as well as production after Karnataka. In Maharashtra, sunflower is grown on an area of $0.05 \mathrm{M}$ ha. with the production of $0.02 \mathrm{M}$. T. and having productivity of $413 \mathrm{~kg}$ ha-1 (Annonimus 2014-2015). Nitrogen (N) is the most significant nutrient to improve yield and quality of sunflower seeds. It is an essential plant nutrient to stimulate plant growth and development and ultimately yield and quality (Ullah et al., 2010). Fertilizer needs of common sunflower cultivars vary based on ecological conditions annul precipitations, irrigation regimes and plant species. Higher nitrogen doses improve photosynthesis process, increase leaf area and net digestion rates (Munir et al., 2007). However, excessive nitrogen treatments may result in environmental pollution, imbalanced plant nutrition, decreased quality and increased production cost (Gokul et al., 2006). Therefore, proper nitrogen doses should be so selected as to improve yield and quality but to prevent negative impacts on human and soil health.

Bio-fertilizers add nutrients through the natural processes of nitrogen fixation, solubilizing phosphorus, and stimulating plant growth through the synthesis of growthpromoting substances. Bio-fertilizers can be expected to reduce the use of chemical fertilizers and pesticides. The microorganisms in bio -fertilizers restore the soil's natural nutrient cycle and build soil organic matter. Through the use of bio-fertilizers, healthy plants can be grown, while enhancing the sustainability and the health of the soil. Biofertilizers are microbial inoculants which have attained special significance in modern agriculture, they have a supplementary and complementary nutritive role in productivity of soil and crop. Azospirillum is a nonsymbiotic associative micro-aerophilic nitrogen fixer. The nitrogen fixation by Azospirillum is upto $20 \mathrm{~kg} / \mathrm{ha}$ (Tandon, 1991). Results of the experiments conducted at different places indicated the possibility of saving upto 25-50 per cent of recommended dose of nitrogen in the presence of Azospirillum in many crops. Besides its direct effect on the current crop, it also leaves considerable residual effect to the succeeding crop. Azotobacter is a free-living heterotrophic nitrogen fixing bacteria. It can provide $30-35 \mathrm{~kg}$ of nitrogen hectare. Crops treated with Azotobacter inoculation integrated with moderate levels of inorganic fertilizer are also known to give yields 
comparable to those with higher doses of mineral fertilizers alone (Wani, 1990)

\section{Materials and Methods}

A field experiment was conducted during kharif season of 2019, at Crop research farm of Department of Agronomy at Sam Higginbottom University of Agriculture, Technology, and Sciences, Prayagraj which is located at $25^{\circ} 24^{\prime} 42^{\prime \prime} \mathrm{N}$ latitude, 81 ${ }^{\circ} 50^{\prime} 56^{\prime \prime} \mathrm{E}$ longitude and $98 \mathrm{~m}$ altitude above the mean sea level (MSL). To assess the effect of Nitrogen and biofertilizers on growth and yield of Sunflower (Helianthus annuus L.). The experiment was laid out in Randomized Block Design comprising of 10 treatments which are replicated thrice. Each treatment net plot size is $3 \mathrm{~m} \times 3 \mathrm{~m}$. First treatment $\left(\mathrm{T}_{1}\right)$ is applied with recommended dose of fertilizers (RDF) $80 \mathrm{~kg} / \mathrm{ha} \mathrm{N}$ ha through urea,60 $\mathrm{kg} / \mathrm{haP}_{2} \mathrm{O}_{5}$ through $\mathrm{SSP}, 40 \mathrm{~kg} / \mathrm{haK}_{2} \mathrm{O}$ through Muriate of Potash. Rest of the treatments applied with Nitrogen Levels in addition with biofertilizers like Azospirillum, Azotobacter, when applied as sole and in combinations as follows, $\left(\mathrm{T}_{2}\right) 60 \mathrm{~kg} / \mathrm{ha} \mathrm{N}+$ Azospirillum, $\left(\mathrm{T}_{3}\right)$ $60 \mathrm{~kg} / \mathrm{ha} \mathrm{N}+$ Azotobacter, $\left(\mathrm{T}_{4}\right) 60 \mathrm{~kg} / \mathrm{ha} \mathrm{N}+$ Azospirillum + Azotobacter, $\left(\mathrm{T}_{5}\right) 70 \mathrm{~kg} / \mathrm{ha} \mathrm{N}+$ Azospirillum, $\left(\mathrm{T}_{6}\right) 70 \mathrm{~kg} / \mathrm{ha} \mathrm{N}+$ Azotobacter, $\left(\mathrm{T}_{7}\right) 70 \mathrm{~kg} / \mathrm{ha} \mathrm{N}+$ Azospirillum + Azotobacter, $\left(\mathrm{T}_{8}\right) 80 \mathrm{~kg} / \mathrm{ha} \mathrm{N}+$ Azospirillum, $\left(\mathrm{T}_{9}\right) 80 \mathrm{~kg} / \mathrm{ha} \mathrm{N}+$ Azotobacter, $\left(\mathrm{T}_{10}\right) 80 \mathrm{~kg} / \mathrm{ha}$ $\mathrm{N}+$ Azospirillum + Azotobacter. Biofertilizers applied as seed treatments. Seeds are treated with Azotobacter and Azospirillum in a liquid form. The Sunflower crop was harvested treatment wise at harvesting maturity stage. After harvesting, seeds were separated from each net plot and were dried under sun for three days. The data was computed and analysed by following statistical method of Gomez and Gomez (1984). The benefit: cost ratio was worked out after price value of grain with straw and total cost included in crop cultivation. After thorough field preparation initial soil samples were taken to analyse for available major nutrients. Nitrogen $(\mathrm{N})$, phosphorous $(\mathrm{P})$, potassium (K), sulphur (S), Organic Carbon (OC), $\mathrm{pH}$ and soluble salts. The type of soil in experimental field is sandy clay. The $\mathrm{pH}$ of the experimental field was 7.3, EC of 0.29 $\mathrm{dSm}^{-1}$, organic carbon was $0.46 \%$. The $\mathrm{N}$ status of the experimental field was low (215 $\mathrm{kg} / \mathrm{ha})$, medium in available $\mathrm{P}(12 \mathrm{~kg} / \mathrm{ha})$ while available $\mathrm{K}$ status was in higher range (232kg/ha).

Growth parameters viz. plant height $(\mathrm{cm})$, dry matter accumulation (g), head diameter $(\mathrm{cm})$ was recorded manually on five randomly selected representative plants from each plot of each replication separately as well as yield and yield attributing character viz. No. of unfilled seed/capitulum, No. of filled seed/capitulum, test weight $(\mathrm{g})$, seed yield ( $\mathrm{kg} / \mathrm{ha})$, Stover yield(kg/ha) were recorded as per the standard method.

\section{Results and Discussion}

Effect on growth parameters: It is evident from Table1 that plant height measured increased with advancement in crop growth. At harvest the treatment $\mathrm{T}_{10}(80 \mathrm{~kg} / \mathrm{ha} \mathrm{N}+$ Azospirillum + Azotobacter) recorded maximum height of $126.21 \mathrm{~cm}$. At harvesting stage maximum plant height was measured in $\mathrm{T}_{10}$ and treatments $\mathrm{T}_{5}, \mathrm{~T}_{6}, \mathrm{~T}_{7}, \mathrm{~T}_{8}$ and $\mathrm{T}_{9}$ were found statistically at par to $\mathrm{T}_{10}$. The highest plant height in treatment $\mathrm{T}_{10}$ may be ascribed due to the continuous supply of nutrients throughout all growth stages with beneficial association between biofertilizers (azotobacter and azospirillum) along with chemical fertilizers. Leaching losses of nutrients must have been minimized by use of biofertilizers, which have ability to mobilize nutritionally important elements from non-usable form to usable forms. 
Table.1 Effect of Nitrogen and Biofertilizers on growth parameters of Sunflower at harvest

\begin{tabular}{|c|c|c|c|}
\hline Treatments & Plant height (cm) & $\begin{array}{c}\text { Plant dry weight } \\
\text { (g/plant) }\end{array}$ & Head diameter $(\mathrm{cm})$ \\
\hline 1. Control (N:P: K - 80:60:40) & 111.07 & 41.89 & 8.92 \\
\hline 2. $60 \mathrm{~kg} / \mathrm{haNitrogen}+$ Azospirillum & 118.05 & 43.26 & 11.05 \\
\hline 3. $60 \mathrm{~kg} / \mathrm{haNitrogen}+$ Azotobacter & 119.29 & 44.54 & 11.87 \\
\hline 4. $60 \mathrm{~kg} / \mathrm{haNitrogen}+$ Azospirillum + Azotobacter & 121.04 & 46.63 & 12.03 \\
\hline $5.70 \mathrm{~kg} / \mathrm{haNitrogen}+$ Azospirillum & 122.01 & 46.54 & 11.65 \\
\hline $6.70 \mathrm{~kg} / \mathrm{haNitrogen}+$ Azotobactor & 122.45 & 47.50 & 12.47 \\
\hline 7. $70 \mathrm{~kg} / \mathrm{haNitrogen}+$ Azospirillum + Azotobactor & 125.33 & 49.50 & 12.96 \\
\hline 8. $80 \mathrm{~kg} / \mathrm{haNitrogen}+$ Azospirillum & 122.91 & 48.97 & 11.54 \\
\hline $9.80 \mathrm{~kg} / \mathrm{haNitrogen}+$ Azotobactor & 124.83 & 50.14 & 12.63 \\
\hline 10. $80 \mathrm{~kg} /$ haNitrogen + Azospirillum + Azotobactor & 126.21 & 52.52 & 13.52 \\
\hline $\operatorname{SEm}( \pm)$ & 1.80 & 1.41 & 0.68 \\
\hline $\mathrm{CD}(\mathrm{P}=0.05)$ & 5.35 & 4.19 & 2.02 \\
\hline
\end{tabular}

Table.2 Effect of Nitrogen and Biofertilizers on yield and yield attributing characters of Sunflower

\begin{tabular}{|c|c|c|c|c|c|}
\hline Treatments & $\begin{array}{c}\text { No. of Filled } \\
\text { seeds/Capitulum }\end{array}$ & $\begin{array}{c}\text { No. of unfilled } \\
\text { seeds / } \\
\text { Capitulum }\end{array}$ & $\begin{array}{c}\text { Test weight } \\
\text { (g) }\end{array}$ & $\begin{array}{l}\text { Seed yield } \\
\mathrm{kg} / \mathrm{ha}\end{array}$ & $\begin{array}{c}\text { Stalk yield } \\
\text { kg/ ha }\end{array}$ \\
\hline 1. Control (N:P: K - 80:60:40) & 265.00 & 33.67 & 31.78 & 840.77 & 2491.15 \\
\hline 3. $60 \mathrm{~kg} / \mathrm{haNitrogen}+$ Azotobacter & 301.00 & 28.33 & 34.65 & 1145.77 & 2775.82 \\
\hline 4. $60 \mathrm{~kg} / \mathrm{haNitrogen}+$ Azospirillum + Azotobacter & 313.00 & 27.33 & 35.29 & 1232.81 & 2883.54 \\
\hline $5.70 \mathrm{~kg} / \mathrm{haNitrogen}+$ Azospirillum & 303.67 & 25.00 & 35.81 & 1167.52 & 2889.47 \\
\hline 7. $70 \mathrm{~kg} /$ haNitrogen + Azospirillum + Azotobactor & 324.33 & 15.67 & 39.63 & 1328.96 & 2941.15 \\
\hline 8. $80 \mathrm{~kg} / \mathrm{haNitrogen}+$ Azospirillum & 311.33 & 19.00 & 38.29 & 1218.6 & 2940.14 \\
\hline 9. $80 \mathrm{~kg} / \mathrm{haNitrogen}+$ Azotobactor & 331.67 & 16.33 & 39.74 & 1260.19 & 2942.90 \\
\hline 10. $80 \mathrm{~kg} /$ haNitrogen + Azospirillum + Azotobactor & 373.67 & 13.33 & 41.10 & 1351.15 & 2954.29 \\
\hline $\operatorname{SEm}( \pm)$ & 7.97 & 0.81 & 1.02 & 13.6 & 18.74 \\
\hline $\mathrm{CD}(\mathrm{P}=0.05)$ & 23.70 & 2.41 & 3.03 & 40.41 & 55.7 \\
\hline
\end{tabular}


Table.3 Effect of Nitrogen and Biofertilizers on economics of Sunflower

\begin{tabular}{|c|c|c|c|c|}
\hline Treatments & $\begin{array}{c}\text { Cost of } \\
\text { cultivation } \\
(₹ / h a)\end{array}$ & $\begin{array}{c}\text { Gross } \\
\text { Return } \\
\text { (₹/ha) }\end{array}$ & $\begin{array}{l}\text { Net return } \\
\text { (₹/ha) }\end{array}$ & $\begin{array}{c}\text { Benefit } \\
\text { cost ratio } \\
\text { (B:C) }\end{array}$ \\
\hline 1. Control (N:P: K - 80:60:40) & 26589 & 47503.51 & 20914.51 & 1.78 \\
\hline 2. $60 \mathrm{~kg} / \mathrm{haNitrogen}+$ Azospirillum & 26588 & 59251.93 & 32663.93 & 2.23 \\
\hline 3. $60 \mathrm{~kg} / \mathrm{haNitrogen}+$ Azotobacter & 26742 & 64735.82 & 37993.82 & 2.42 \\
\hline 4. $60 \mathrm{~kg} / \mathrm{haNitrogen}+$ Azospirillum + Azotobacter & 27189 & 69653.95 & 42464.95 & 2.56 \\
\hline $5.70 \mathrm{~kg} / \mathrm{haNitrogen}+$ Azospirillum & 26588 & 65964.69 & 39376.69 & 2.48 \\
\hline $6.70 \mathrm{~kg} / \mathrm{haNitrogen}+$ Azotobactor & 26742 & 70407.10 & 43665.10 & 2.63 \\
\hline 7. $70 \mathrm{~kg} / \mathrm{haNitrogen}+$ Azospirillum + Azotobactor & 27189 & 75086.05 & 47897.05 & 2.76 \\
\hline $8.80 \mathrm{~kg} / \mathrm{haNitrogen}+$ Azospirillum & 26588 & 68850.71 & 42262.71 & 2.59 \\
\hline $9.80 \mathrm{~kg} / \mathrm{haNitrogen}+$ Azotobactor & 26742 & 71200.93 & 44458.93 & 2.66 \\
\hline 10. $80 \mathrm{~kg} / \mathrm{haNitrogen}+$ Azospirillum + Azotobactor & 27189 & 76339.98 & 49150.98 & 2.81 \\
\hline
\end{tabular}

According to Tisdale et al., 2003 in addition to its high $\mathrm{N}$ fixation and biofertilizersis known to synthesize growth substances such as IAA and other auxines and vitamins B which might have also helped in growing the plant height. The treatment $\mathrm{T}_{10}(80 \mathrm{~kg} / \mathrm{ha} \mathrm{N}+$ Azospirillum + Azotobacter) recorded maximum dry matter accumulation of52.52 (g) at the harvesting stage and however $\mathrm{T}_{7}$, $\mathrm{T}_{8}$, and $\mathrm{T}_{9}$ treatments are found statistically at par to maximum dry matter accumulation. Shaukat et al., (2006) stated that all the bacterial strains significantly stimulated the growth and yield parameters under field conditions, when compared with that of the control, associated with increase in auxin and protein contents as well as peroxidase and acid phosphate activities. The maximum head diameter was recorded at harvest in treatment $\mathrm{T}_{10}(80 \mathrm{~kg} / \mathrm{ha} \mathrm{N}+$ Azospirillum + Azotobacter $)$ was significantly superior over all other treatment but the treatment $\mathrm{T}_{5}(70 \mathrm{~kg} / \mathrm{ha} \mathrm{N}+$ Azospirillum), $\mathrm{T}_{6}(70 \mathrm{~kg} / \mathrm{ha} \mathrm{N}+$ Azotobactor $)$ and $\mathrm{T}_{7} \quad(70 \mathrm{~kg} / \mathrm{ha} \mathrm{N}+$ Azospirillum + Azotobactor $), \quad \mathrm{T}_{8} \quad(80 \quad \mathrm{~kg} / \mathrm{ha} \quad \mathrm{N}+$ Azospirillum), $\mathrm{T}_{9}(80 \mathrm{~kg} / \mathrm{ha} \mathrm{N}+$ Azotobactor) were found at par with the treatment $\mathrm{T}_{10}$. The maximum head diameter recorded was 13.52 $\mathrm{cm}$ by treatment $\mathrm{T}_{10}$ at harvest. The lowest head diameter was observed with treatment
$\mathrm{T}_{1}$ (control). The increase of head diameter may be due to more photosynthetic activities of the plant on the account of adequate supply of nitrogen in this treatment which include $\mathrm{MN}, \mathrm{ONF}$ and bio fertilizers, since nitrogen has an important role in encouraging cell elongation, cell division and consequently increasing vegetative growth and activation of photosynthesis process which enhance the number of metabolites necessary for building plant organs (Wajid et al., 2012).

\section{Yield and Yield Attributes}

Among all the treatments the highest filled seeds/capitulum was observed in Treatment $\mathrm{T}_{10}(80 \mathrm{~kg} / \mathrm{ha} \mathrm{N}+$ Azospirillum + Azotobacter $)$ recorded maximum number of filled seed per plant (373.67) and it was found significantly superior over all treatments. The lowest number of filled seeds per plant was recorded for treatment $\mathrm{T}_{1}$ i.e. (Control) (265) followed by $\mathrm{T}_{2}(60 \mathrm{~kg} / \mathrm{ha} \mathrm{N}+$ Azospirillum $)$ seed treatments.

Vessey (2003) reported that Azotobacter and Azospirillum increase the available nitrogen in the soil which could enhance the grain number. Grain yield was significantly influenced with different combinations of 
biofertilizers with chemical fertilizers. The maximum yield $(1315.15 \mathrm{~kg} / \mathrm{ha}) \quad$ was observed with $\mathrm{T}_{10}(80 \mathrm{~kg} / \mathrm{ha} \mathrm{N}+$ Azospirillum + Azotobacter). The increase in yield and yield attributing parameters might due to the application of the combined use of inorganic fertilizers, organic manures and bio fertilizers can enhance the inherent nutrients supplying capacity of the soil with respect to both macro- and micronutrients (Jayabal and Chelliah, 2000) and also improve the physical properties of the soil, which promote better rooting, higher nutrient uptake by the crop and increase in seed yield. The increase in yield due to biofertilizers inoculates may not be solely due to $\mathrm{N}$ fixation or phosphate solubilisation, but because of several other factors such as release of growth promoting substances, control of plant pathogen, proliferation of beneficial organism in the azotobactor and Azospirillum. The highest stalk yield was observed in treatment $\mathrm{T}_{10}(80$ $\mathrm{kg} / \mathrm{ha} \mathrm{N}+$ Azospirillum + Azotobacter $)$ (2954.29) found significantly superior over all other treatments and which is at par to the $\mathrm{T}_{7}$ (2941.15), $\mathrm{T}_{8}$ (2940.14) and $\mathrm{T}_{9}$ (2942.90). The lowest stalk yield was observed for the treatment $\mathrm{T}_{1}$ (Control). This shows that, on stalk yield was the real effect of various treatment applied. The increase in straw yield might be because more amount of nitrogen availability through bio fertilizers. Nitrogen is known to promote improve length and width of leaves, which in turn increase the dry matter and are responsible for increase in straw yield

\section{Economics}

Among the all treatments application of 80 $\mathrm{kg} / \mathrm{ha} \mathrm{N}+$ Azospirillum + Azotobacter recorded significantly maximum Higher Gross returns (76339.98 ₹/ha), Net returns (49150.98 ₹/ha) and Benefit Cost Ratio (2.81) were obtained with application of (80 $\mathrm{kg} / \mathrm{ha}$ Nitrogen + Azospirillum + Azotobactor .
The yield advantage through application of azotobacter with more proportional increase in cost of cultivation which has been statistically superior over other treatments but treatment with biofertilizers. The enhancement in the NAR was accredited due to maximum vegetative growth as explained by Abelardo \& Hall (2002) that was higher as in response with the application of nitrogen fertilizer.

On the basis of one year of experimentation it may be concluded that application of $80 \mathrm{~kg} / \mathrm{ha}$ $\mathrm{N}+$ Seed treatment of Azospirillum and Azotobacter recorded higher Seed yield $(1351.15 \mathrm{~kg} / \mathrm{ha})$ as well as with greater (B:C ratio 2.81)Since the findings were based on the research done in one season it may be repeated for further confirmation and recommendation.

\section{Acknowledgements}

The authors are thankful to Department of Agronomy, Naini Agricultural Institute, Sam Higginbottom University of Agriculture Technology and Sciences, Prayagraj, (U.P.) India for providing field, facilities and assistance in conducting this research.

\section{References}

Abdel-Salam A. A., Soliman S.M., Galal Y.G.M., Zahral W.R., Moursy A. A. and Hekal M. A. (2015). Response of Sunflower (Helianthus annuus L.) to Napplication and biofertilization with assessment of fertilizer $\mathrm{N}$ recovery by $\mathrm{N}$ versus subtraction methods., J. Nucl. Tech. Appl. Sci, Vol. 3, No. 3, PP. 157: 169.

Dhanasekar, R. and Dhandapani, R. (2012). Effect of biofertilizers on the growth of Sunflower (Helianthus annuus L.). International Journal of Plant, Animal and Environmental Sciences Vol. 2 No. 
4.

Gehan, G.Mostafa and AboBaker, A.A.(2010). Effect of bio and chemical fertilization on growth of Sunflower (Helianthus annuus L.) at south valley area. Asian Journal of Crop Science, 2:137-146.

Gomez, K.A., Gomez, A.A.2010. Statistical procedures for agricultural research. $2^{\text {nd }}$ edn. Wiley India Pvt Ltd, India.

Goksoy, A.T. and Turan, Z.M., 2007. Correlations and path analysis of yield components in synthetic varieties of sunflower (Helianthus annuus L.). Acta AgronomicaHungarica 10: 339-345

Jackson, N. L. 1973. Soil Chemical analysis. Prentice Hall of India Pvt. Ltd. New Delhi.

Jayabal A; S.P. Palayyappan and S. Chelliah (2000). Effect of integrated nutrient management techniques on yield attributes and yields of sunflower (Helianthus annuus L). Ind. J. Agron. 45(2) $384-386$.

Marschner, H., 1995. Mineral Nutrition of Higher Plants (2nd Ed.). Academic Press Ltd. London. U.K. pp. 229-312.

Martyniuk S, Martyniuk M. Occurrence of Azotobacter spp. in some polish soils. Polish J Environ Stud. 2003;12(3):371374.

Mirparsa T, Ganjali HR and Dahmardeh M, (2016). The effect of bio fertilizers on yield and yield components of sunflower oil seed and nut. Inter $J$ Agriculture Biosci., 5(1):46- 49.

Panse, V.G., Sukhatme, P.V., (1967). Statistical methods for agricultural research workers. ICAR Publication, New Delhi.

Soleimanzadeh, H., Habibi, D., Ardakani, M.R., Paknejad, F.andRejali, F.(2010).Response of sunflower (Helianthus annum L.) to inoculation with azotobacter under different nitrogen levels. American-Eurasian J. Agric. \& Environ. Sci., 7 (3):265-268.

Subbiah, B. Vand Asija, G.L. 1956. A rapid procedure for estimation of available nitrogen in soils. Current Science. 25: 259-260.

Shaukat, K., S. Afrasayeb. and S. Hasnain, 2006. Growth response of Helianthus annuus to plant growth promoting rizobacteria used as a biofertilizers. Int. J. Agric. Res., 1: 573-581

Toosi Abbas Fallah and Azizi Mehdi (2014). Effect of different sources of nitrogen fertilizer on yield \& yield components of Sunflower (Helianthus annuus L.). Scientific Papers. Series A. Agronomy., Vol. LVII

Wajid N.; A. Ashfaq; M. H. Hafiz; J. C. Hassan and F. H. Muhammad. (2012). Effect of nitrogen on growth and yield of sunflower under semi-arid conditions of Pakistan. Pak. J. Bot., (44) 639-648.

\section{How to cite this article:}

Lakshman Jonnagorla, Vikram Singh, Dhananjay Tiwari, Shaik Mahaboob Ali and Balla Hari Krishna. 2021. Effect of Levels of Nitrogen and Biofertilizers on Growth and Yield of Sunflower (Helianthus annuus L.). Int.J.Curr.Microbiol.App.Sci. 10(01): 2196-2202. doi: https://doi.org/10.20546/ijcmas.2021.1001.252 